\title{
Effects of hyper- and hypothyroid on expression of thyroid hormone receptor mRNA in rat myocardium
}

\author{
C R Liu', L Y Li, F Shi, X Y Zang, Y M Liu', Y Sun and B H Kan \\ Key Laboratory of Hormones and Development, Ministry of Health China, Endocrinology Institute of Tianjin Medical University, Tianjin Medical Institute, Tianjin \\ 300070, China \\ ${ }^{1}$ Department of Pathology, Medical College of Chinese People's Armed Police Force, Tianjin 300162, China \\ (Correspondence should be addressed to LY Li; Email: lily@tijmu.edu.in)
}

\begin{abstract}
Thyroid dysfunction is classified into hyperthyroidism and congenital hypothyroidism $(\mathrm{CH})$. Both hyperthyroidism and $\mathrm{CH}$ can cause heart lesions; however, the mechanisms involved remain unclear. The left ventricle was collected from eu-, hyper-, and hypothyroid rat. RNA was extracted and reverse-transcripted to cDNA. Real-time fluorescence quantitation-PCR was used to quantify the differential expression of thyroid hormone receptor (TR) subtype mRNA among eu-, hyper-, and hypothyroid rat myocardium. Here, we show that compared with the normal myocardium, TR $\alpha 1$ mRNA expression was upregulated by $51 \%$ $(P<0 \cdot 01)$, TR $\alpha 2$ mRNA expression was downregulated by $58 \%$ $(P<0 \cdot 01)$, and TR $\beta 1 \mathrm{mRNA}$ expression remained unchanged in hyperthyroid rat myocardium $(P>0 \cdot 05)$. TR $\alpha 1, \mathrm{TR} \alpha 2$, and
\end{abstract}

TR $\beta 1$ were expressed in normal and hypothyroid rat myocardium throughout the developmental process. In hypothyroid rats, myocardial TR $\alpha 1$ mRNA expression was generally downregulated and the expression peak appeared late. Myocardial TR $\propto 2$ mRNA expression was generally upregulated and the expression peak appeared late. Myocardial TR $\beta 1 \mathrm{mRNA}$ expression was generally downregulated and changed similarly with the control group. In addition, the hypogenetic myocardium can be seen in the hypothyroid rat by pathology study. Taken together, the abnormal expression of TR subtype mRNA may have a close relationship with the pathogenesis of $\mathrm{CH}$ and hyperthyroidism heart disease.

Journal of Endocrinology (2007) 195, 429-438

\section{Introduction}

The heart is a major target organ for thyroid hormone (tri-iodothyronine, $\mathrm{T}_{3}$ ) action. Thyroid hormone exerts its biological effects largely by influencing thyroid hormoneregulated gene expression via interactions with the highaffinity thyroid hormone receptor (TR) located in the nucleus. TR plays an important role in mediating the cardiac physiologic actions of $\mathrm{T}_{3}$ (Sussman 2001, Dillmann 2002).

Normal thyroid hormone level is essential for maintaining normal heart structure and function. In clinical settings, patients with hyperthyroidism or congenital hypothyroidism $(\mathrm{CH})$ may present abnormalities in myocardial structure and heart function. Changes in thyroid status exert marked influences on the contractile and electrophysiological function of the heart. The molecular basis of alterations in electrophysiological function caused by changes in different thyroid hormone status has not been completely explored.

Besides aggravating preexisting ischemic heart disease or other types of heart disease, hyperthyroidism itself may cause atrial fibrillation, cardiac dilatation, heart failure, angina pectoris, or myocardial infarction. The incidence of hyperthyroid heart disease was 10 to $20 \%$ among hyperthyroidism patients. Hyperthyroidism is frequently complicated by arrhythmia and, most commonly by atrial fibrillation (Klein \& Ojamaa 2001). Current studies have demonstrated the possible association of atrial fibrillation with $\mathrm{Na}^{+}-\mathrm{K}^{+}$-ATPase. The maintenance of atrial fibrillation depends on the formation of multiple reentrant cycles. In hyperthyroidism, the activity of $\mathrm{Na}^{+}-\mathrm{K}^{+}$-ATPase is enhanced in myocardial cells, which promotes $\mathrm{Na}^{+}$outflow and $\mathrm{K}^{+}$inflow and thus shortens the duration of action potential of individual atrial muscle cell (Rensma et al. 1988, Wijffels et al. 1995, Maixent et al. 2000, Workman et al. 2003). In addition, shortening of the action potential duration in the ventricular muscle and concomitant tachycardia may render the ventricle susceptible to developing heart failure known as thyrotoxic heart (Klein 1990, Polikar et al. 1993). Hyperthyroidism that has been existing for a long time and has not been treated can result in marked morphological changes of the heart, including atrial or ventricular dilatation, heart weight gain, hypertrophy of myocardial cells, widened spaces between the muscle fibers of the heart (Henle's fissures), and ultimately necrosis of myocardial cells and heart failure. The factors below may be associated with these myocardial pathologies: 1) hyperthyroid symptom is similar to sympathetic nerve system. Furthermore, tachycardia, increased pulse pressure, higher cardiac output, and oxygen wastage caused by hyperthyroidism can be successfully alleviated using sympathetic nerve or $\beta$-receptor retarder. Therefore, it was 
estimated that hyperthyroid myocardium injury may be related with sympathetic-adrenalin system (Morgan \& Baker 1991). 2) In hyperthyroidism, the renin-angiotensin-aldosterone system (RAAS) is activated, the plasma rennin activity is enhanced, the concentrations of angiotensinogen and angiotensin (AT) are increased, and the density of AT receptor in the heart is upregulated. Activation of the RAAS adversely influences the cardiovascular system: on the one hand, it increases blood volume and the heart's burden and, on the other, AT binds to high-affinity AT receptors on myocardial cells or vascular smooth muscle cells and stimulates c-fos gene transcription in the nucleus through the intracellular signal transduction system. The c-fos protein can promote growth of myocardial or vascular smooth muscle cells and lead to myocardial hypertrophy. As a result, compensated myocardial function turns decompensated followed by heart failure (Katz 1990, Morgan \& Baker 1991, Marchant et al. 1993, Sernia et al. 1993, Basset et al. 2001). These findings were derived from biochemical research on the pathogenesis of hyperthyroid heart disease. As for molecular research on the pathogenesis of hyperthyroid heart disease, thyroid hormone-regulated genes have been the major concern. It was demonstrated that myocardial genes upregulated by thyroid hormone include HCN2, HCN4, myosin heavy chain $\alpha$ (MHC $\alpha)$, and sarcoplasmic reticulum calcium-activated ATPase2 (SERCA2), and myocardial genes downregulated by thyroid hormone include $\mathrm{MHC} \beta$ and $\mathrm{Na}^{+} / \mathrm{Ca}^{+}$exchanger (Dillmann 1990, 1996, Kahaly \& Dillmann 2005). Despite the aforementioned findings, TR, a factor closely associated with the physiologic functions of thyroid hormone, has not been fully investigated and few studies of the association between hyperthyroid heart disease and TR subtypes have been reported.

$\mathrm{CH}$ is a relatively common newborn endocrine disorder that occurs with a frequency of $\sim 1: 3500$. CH may cause cretinism and myxedema in different age groups. During the fetal and infantile periods, inadequate thyroxin derived from the maternal body or synthesized may cause $\mathrm{CH}$ (cretinism). The patient usually presents with myocardial structural developmental abnormalities and serious heart dysfunction, a condition called hypothyroid heart disease. Adult hypothyroid heart disease was first reported by Zondek in 1918. In CH patients, heart damage is very common. It is now thought that $70-80 \%$ of hypothyroidism patients have cardiovascular lesions, typically hypothyroid coronary heart disease, hydropericardium, cardiomyopathy, or pericarditis with cardiomyopathy (Balducci et al. 1991, Di Meo et al. 1994, Chao et al. 1997). Many patients visit the cardiovascular departments because of heart damages as initial manifestations. Due to diversified clinical manifestations and a chronic disease course, it is very easy to misdiagnose $\mathrm{CH}$ as another disease. Hence, to deepen the understanding of the pathogenesis of hypothyroid heart damages is important to increase the life quality of hypothyroid patients. To date, there have been only some pathomorphological reports on hypothyroid heart disease. Nevertheless, few studies of the pathogenesis of hypothyroid heart disease have been reported. In particular, the effect of
$\mathrm{CH}$ on myocardial TR subtype mRNA expression at different developmental stages has not yet been reported.

Taken together, thyroid hormone exerts crucial regulatory actions on maintaining normal relaxation and contraction and electrophysiology of the heart. Abnormal thyroid hormone concentrations may lead to myocardial structural and functional abnormalities. Thus far, the pathogenesis of hyper- and hypothyroid heart disease has not been completely elucidated. TR plays an important role in mediating the physiologic actions of thyroid hormone. Whether abnormal thyroid hormone concentrations influence myocardial expression of TR, and whether the pathogenesis of hyper- and hypothyroid heart disease is associated with TR are issues worthy of investigation. It is believed that unraveling these issues will open a new avenue to clinical treatment of these disorders. In order to explore the association between TR and heart lesions during thyroid dysfunction and to provide a new therapeutic strategy for hyper- and hypothyroid heart disease at the molecular level, differential expressions of TR subtype mRNAs among normal, hyperthyroid, and hypothyroid rat myocardium were analyzed using fluorescence quantitation-PCR (FQ-PCR).

\section{Materials and Methods}

\section{Experimental animals}

All animals were obtained from the Experimental Animal Centre of the Academy of Military Medical Sciences of China. They were raised in a temperature-controlled room $\left(21-23{ }^{\circ} \mathrm{C}\right)$ under a $12 \mathrm{~h}$ light:12 h darkness cycle. Food and water were freely available.

Hyperthyroid animals Sixteen Wistar rats (specific pathogen-free animals, weighing 150-180 g) were equally randomized to the control group and the experimental group $(n=8)$. Thyroxin tablets (Shanghai Great Wall Pharmaceutical, Shanghai, China) were ground and diluted with normal saline into a $40 \mathrm{~g} / \mathrm{l}$ suspension. Each rat from the experimental group and the control group (Morreale de Escobar et al. 1988) was intragastrically administered $1 \mathrm{ml}$ suspension and normal saline respectively, once a day, for 3 successive weeks. After 3 weeks of treatment, the animals were weighed and anesthetized with 1\% pentobarbital, followed by thoracotomy and blood sampling from the heart. Blood samples were centrifuged and the supernatants were obtained for detecting serum free $T_{3}\left(F_{3}\right)$ and free thyroxine $\left(\mathrm{FT}_{4}\right)$ levels by RIA (completed by radiology Institute of Tianjin Medical University). The heart was obtained and blood in the cardiac chamber was washed out quickly with diethylpyrocarbonate (DEPC) water. The heart was wiped dry with a sheet offilter paper, weighed, and stored in liquid nitrogen.

Hypothyroid animals Twelve pregnant Wistar rats (specific pathogen-free animals) were equally randomized into the experimental group and the control group. From the 15th day of gestation, each rat from the experimental group was 
intragastrically administered with $2.5 \mathrm{ml}$ of $1 \%$ propylthiouracil (Dr Herbrand KG, Chem-Pharm. Works, D-77723 Gengenbach, Germany) daily until postnatal 15-day. Litters were $\mathrm{CH}$ rats (Gilbert \& Paczkowski 2003). In contrast, from the 15th day of gestation, each rat from the control group was intragastrically administered with $2.5 \mathrm{ml}$ normal saline daily until postnatal 15 days. At postnatal days 0 (P0d), 14 (P14d), 21 (P21d), and 45 $(\mathrm{P} 45 \mathrm{~d})$, the rats were weighed and killed, and their blood samples were collected from the heart. Serum $\mathrm{FT}_{3}$ and $\mathrm{FT}_{4}$ levels were dynamically determined by RIA (completed by radiology Institute of Tianjin Medical University). The heart was obtained and blood in the cardiac chambers was washed out quickly with DEPC water. The heart was wiped dry with a sheet of filter paper, weighed, and stored in liquid nitrogen. There were 40 neonate rats in total and each subgroup contained 5 of them $(n=5)$.

\section{Total RNA extraction}

Total RNA was isolated from the left ventricle (because this part of the heart makes the major contribution to total cardiac RNA; Gloss et al. 2001) with Trizol reagent, as described by the manufacturer (Gibco, Invitrogen Corporation). Total RNA was quantified by absorbance at $260 \mathrm{~nm}$. The integrity of RNA was assessed by electrophoresis in agaroseformaldehyde gels. Equal amounts of RNA were subjected to reverse transcription to synthesize cDNAs (Reverse Transcription System, Promega Co).

\section{PCR}

PCR was carried out in a total reaction volume of $20 \mu \mathrm{l}$ containing $4 \mu \mathrm{l}$ cDNA. The 30 cycles of PCR amplification were preceded by a heat denaturing step at $95^{\circ} \mathrm{C}$ for $5 \mathrm{~min}$. Each cycle of PCR consisted of denaturation at $95^{\circ} \mathrm{C}$ for $30 \mathrm{~s}$, annealing at $60{ }^{\circ} \mathrm{C}$ for $30 \mathrm{~s}$, and extension at $72{ }^{\circ} \mathrm{C}$ for $30 \mathrm{~s}$. The PCR was terminated with a prolonged extension step at $72^{\circ} \mathrm{C}$ for $5 \mathrm{~min}$. Primers were designed with Gene Runner Analysis software (Hastings Software Inc., Hastings on Hudson, NY,
USA). The nucleotide sequences for the primers were listed in Table 1. Products were electrophoresed in 1.5\% agarose gels, stained with ethidium bromide, and visualized under u.v. light.

\section{Preparation of FQ-PCR standards}

TR $\alpha 1$, TR $\alpha 2$, TR $\beta 1$, and glyceraldehyde-3-phosphate dehydrogenase (GAPDH) target fragments were recovered and purified from $1 \cdot 5 \%$ agarose gel using a PCR product purification kit (Beijing BioDev-Tech Co., Ltd, Beijing, China). The target fragments were cloned into PMD18-T vector (TIANGEN Biotech Co., Ltd, Beijing, China) respectively and the recombinants were transformed into competent $\mathrm{DH} 5 \alpha$ bacteria, followed by screening of positive clones. Recombinant plasmidcarrying bacteria suspension was sent to Shanghai Bioasia Co., Ltd for sequencing analysis. Meanwhile, recombinant plasmids were extracted and A260 values were measured to clear the concentration of each recombinant plasmid. The copy number of recombinant plasmids was converted as follows: copy number $=$ mass $(\mathrm{g}) \times 6 \cdot 023 \times 10^{23} / 660 \times$ base number. The solution of plasmids was diluted to $10^{8}, 10^{7}, 10^{6}, 10^{5}, 10^{4}$, and $10^{3}$ copy/ $\mu 1$ respectively. Thus, FQ-PCR standards for TR $\alpha 1$, TR $\alpha 2$, TR $\beta 1$, and GAPDH were obtained. The standards were stored at $-20^{\circ} \mathrm{C}$ before use.

\section{Plotting FQ-PCR standard curve}

TaqMan probes (with the fluorescent substance 6-carboxyfluorescein (FAM) at the $5^{\prime}$-terminal and the fluorescence quencher 6-carboxytetramethylrhodamine (TAMRA) at the $3^{\prime}$-terminal) were synthesized according to the sequences as listed in Table 1 (Shanghai Bioasia Co., Ltd, Shanghai, China). FQ-PCR amplification was carried out using the following cycle conditions: Stage 1 (denaturation), $95^{\circ} \mathrm{C}$ for $5 \mathrm{~min}$; Stage 2 (amplification), 40 cycles of $95^{\circ} \mathrm{C}$ for $15 \mathrm{~s}, 63^{\circ} \mathrm{C}$ for $40 \mathrm{~s}$; Stage 3 (melting curve), $95^{\circ} \mathrm{C}$ for $0 \mathrm{~s}, 45^{\circ} \mathrm{C}$ for $15 \mathrm{~s}, 95^{\circ} \mathrm{C}$ for $0 \mathrm{~s}$; and Stage 4 (cooling), $40^{\circ} \mathrm{C}$ for $30 \mathrm{~s}$. FQ-PCR standards were amplified using Roche Lightcycler System for real-time PCR to determine the correlation of the standard curve.

Table 1 Nucleotide sequences for thyroid hormone receptor $\alpha 1$ (TR $\alpha 1$ ), TR $\alpha 2$, TR $\beta 1$, and glyceraldehyde-3-phosphate dehydrogenase (GAPDH) primers and TaqMan probe

\begin{tabular}{|c|c|c|}
\hline & Nucleotide sequences & Amplification site \\
\hline \multicolumn{3}{|l|}{ Target } \\
\hline \multirow[t]{3}{*}{$\operatorname{TR} \propto 1$} & Sense $5^{\prime}$-TGCССТTACTCACСССТАСA- $3^{\prime}$ & $1897-1916$ \\
\hline & Antisense $5^{\prime}$-AAGCCAAGCCAAGCTGTCCT-3' & $2009-2028$ \\
\hline & Probe $5^{\prime}$-TTCAGGCCACAGGTCTCTACTTCCC- $3^{\prime}$ & $1960-1984$ \\
\hline \multirow[t]{3}{*}{$\mathrm{TR} \alpha 2$} & Sense 5'-TGAGCAGCAGTTTGGTGAAG- $3^{\prime}$ & $1211-1230$ \\
\hline & Antisense 5'-GAATGGAGAATTCCGCTTCG-3' & $1308-1327$ \\
\hline & Probe $5^{\prime}$-TTCAGCACCAGAGCCCGAAGAG-3' & $1255-1276$ \\
\hline \multirow[t]{3}{*}{ TRß1 } & Sense 5'-AGCCAGCCACAGCACAGTGA-3' & $4017-4036$ \\
\hline & Antisense 5'-CGCCAGAAGACTGAAGCTTGC-3' & $4116-4136$ \\
\hline & Probe 5'-ACGAACCAGGCTGTAGCAACCGTGG-3' & 4068-4092 \\
\hline \multirow[t]{3}{*}{ GAPDH } & Sense 5'-CCTGGAGAAACCTGCCAAGT-3' & $1587-1605$ \\
\hline & Antisense $5^{\prime}$-TGGGAGTTGCTGTTGAAGTC-3' & $1696-1715$ \\
\hline & Probe 5'-CATCAAGAAGGTGGTGAAGCAGGC-3' & $1614-1637$ \\
\hline
\end{tabular}




\section{FQ-PCR detection of samples}

Total RNA was extracted from myocardial samples. cDNAs were obtained by reverse transcription and then amplified along with the standards using Roche Lightcycler System. The amplification conditions were the same for both the sample cDNAs and the standard cDNAs. Thus, the copy number of TR $\alpha 1, \operatorname{TR} \alpha 2$, TR $\beta 1$, and GAPDH mRNA per $\mu$ l was calculated for each of the samples. Following each FQ-PCR, a melting curve analysis was performed to ensure the specificity of FQ-PCR.

\section{Pathologic study}

Rat hearts from the $\mathrm{CH}$ group and the control group were washed with DEPC water to remove blood in the cardiac chambers and then stored in liquid nitrogen. Rat hearts were sectioned into a thickness of $\sim 10 \mu \mathrm{m}$ using a thermostatic freezing microtome CM1850 (Leica, Leica Microsystems Gmbh, Wetzlar, Germany) at $-20{ }^{\circ} \mathrm{C}$. The tissue was loaded onto glass slides, fixated in a mixture of $95 \mathrm{ml}$ of $95 \%$ ethanol and $5 \mathrm{ml}$ glacial acetic acid for $1 \mathrm{~min}$, and washed with running water. The sections were subjected to routine hematoxylin and eosin (HE) staining, mounting with neutral resin, and photography using an Olympus image analyzer (Olympus, Tokyo, Japan).

\section{Statistical analysis}

Each experiment was repeated thrice. All data were expressed as means \pm s.D. TR $\alpha 1, T R \alpha 2$, and TR $\beta 1 \mathrm{mRNA}$ levels were analyzed by independent samples $t$-test to determine whether the expression of mRNAs encoding TR receptors varied between normal and hyperthyroid groups or between normal and congenital hypothyroid groups. Levels of expression of each mRNA detected were normalized to GAPDH mRNA. $P<0 \cdot 05$ was considered to be significant.

\section{Results}

\section{Hyperthyroid animals}

Compared with the control group, the weight of rats from the hyperthyroid group increased more slowly, the heart rate (HR) was faster, and serum $\mathrm{FT}_{3}$ and $\mathrm{FT}_{4}$ levels were higher $(P<0 \cdot 01)$. Hyperthyroid rats were irritable, they ate and drank significantly more, and their hair lacked luster. Macroscopic observations revealed obvious myocardial hypertrophy and cardiac chamber narrowing in hyperthyroid rats (5/8), and heart weight was higher in the hyperthyroidism group than in the control group $(P<0 \cdot 01$; Tables 2 and 3$)$.

\section{Hypothyroid animals}

The neonate mortality rate was higher in the hypothyroid group $(30 \%)$ than in the control group. Hypothyroid rats grew slowly and were small with a short tail. They opened their eyes late. Their hair grew slowly and was sparse. They were weaned late. Their balancing capability was poor and they reacted to stimuli slowly. The body weights (BW) of P0d, P14d, P21d, and P45d hypothyroid rats were lower than those in the corresponding control group $(t=3 \cdot 97,8 \cdot 66,8 \cdot 91,5 \cdot 72, P<0 \cdot 01)$. The $\mathrm{FT}_{3}$ levels of P0d, P14d, and P21d hypothyroid rats were lower than those in the corresponding control group $(t=2 \cdot 84,5 \cdot 81,5 \cdot 20$, $P<0 \cdot 01)$. The $\mathrm{FT}_{4}$ levels of P0d, P14d, and P21d hypothyroid rats were lower than those in the corresponding control group $(t=3 \cdot 64,6 \cdot 98,4 \cdot 97, P<0 \cdot 01$; Table 4$)$.

\section{PCR results of TRs}

Sequencing results indicated that the sequences of target genes in the recombinant plasmids were identical to those registered in the GenBank database (Fig. 1).

\section{FQ-PCR standard curve}

As shown (Fig. 2), the points standing for the concentration gradients were in a straight line, with a correlation coefficient of $1 \cdot 00$, which denoted a high reliability of the standard curve. The melting curve analysis displayed the single specific product peak appearing per test, which ensured the specificity of FQ-PCR. FQ-PCR standard curve was plotted with the logarithms of initial copy numbers of the standard preparations as abscissa and $C_{t}$ values as ordinate. There was good linearity between $C_{t}$ values and the logarithms of initial copy numbers of the standard preparations $(r=-1 \cdot 00)$.

Differential expression of $m R N A$ for $T R \alpha 1, T R \alpha 2$, and $T R \beta 1$ between normal and hyperthyroid rats myocardium

Compared with the normal myocardium, TR $\alpha 1$ mRNA expression was upregulated by $51 \%(t=9 \cdot 17, P<0 \cdot 01)$, TR $\alpha 2$ mRNA expression was downregulated by $58 \%$ $(t=10 \cdot 02, P<0 \cdot 01)$, and TR $\beta 1 \mathrm{mRNA}$ expression remained

Table 2 Body weight (BW) changes in control and hyperthyroid rats $(n=8, \bar{X} \pm S, g)$

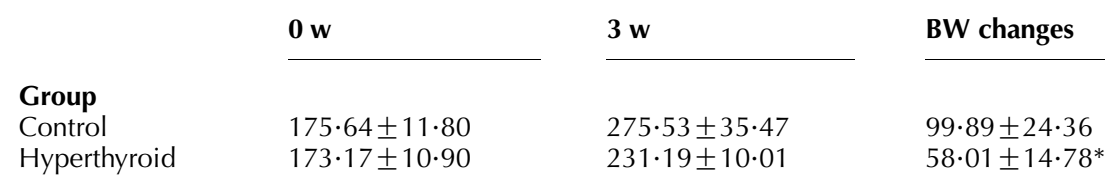

The weight of rats from the hyperthyroid group increased more slowly than the control group. $t=4 \cdot 158$. $* P<0 \cdot 01$ versus control group. 
Table 3 Serum free tri-iodothyronine $\left(\mathrm{FT}_{3}\right)$ and free thyroxine $\left(\mathrm{FT}_{4}\right)$ levels, heart rate $(\mathrm{HR})$, and heart weight $(\mathrm{HW})$ in control and hyperthyroid rats $(n=8, \bar{X} \pm S)$

\begin{tabular}{|c|c|c|c|}
\hline & Control & Hyperthyroid & $t$ \\
\hline $\mathrm{FT}_{3}(\mathrm{pmol} / \mathrm{l})$ & $1 \cdot 01 \pm 0 \cdot 23$ & $9 \cdot 99 \pm 2 \cdot 22 *$ & $11 \cdot 37$ \\
\hline $\mathrm{FT}_{4}(\mathrm{pmol} / \mathrm{l})$ & $18 \cdot 46 \pm 4 \cdot 54$ & $62 \cdot 99 \pm 12 \cdot 27^{*}$ & $9 \cdot 63$ \\
\hline HR (beats/min) & $439 \cdot 13 \pm 25 \cdot 71$ & $527 \cdot 75 \pm 26 \cdot 47^{*}$ & $6 \cdot 79$ \\
\hline $\mathrm{HW}(\mathrm{g})$ & $0.95 \pm 0 \cdot 16$ & $1 \cdot 32 \pm 0 \cdot 16^{*}$ & $4 \cdot 57$ \\
\hline
\end{tabular}

Serum $\mathrm{FT}_{3}$ and $\mathrm{FT}_{4}$ levels, heart rate, and heart weight were higher in the hyperthyroid group than in the control group. ${ }^{*} P<0 \cdot 01$ versus control group.

unchanged in hyperthyroid rat myocardium $(t=0.96$, $P>0 \cdot 05$; Fig. 3$)$.

\section{Differential expression of $m R N A$ for $T R \alpha 1, T R \alpha 2$, and $T R \beta 1$ between normal and hypothyroid rats myocardium}

TR $\alpha 1$, TR $\alpha 2$, and TR $\beta 1$ were expressed in normal and hypothyroid rat myocardium throughout the developmental process.

In normal rat myocardium, TR $\alpha 1 \mathrm{mRNA}$ expression was the highest at birth and then decreased gradually to the adult levels. Compared with normal rat myocardium, TR $\alpha 1$ mRNA expression was downregulated by $90 \%$ at $\mathrm{P} 0 \mathrm{~d}$ $(t=18 \cdot 91, P<0 \cdot 01), 25 \%$ at P21d $(t=3 \cdot 94, P<0 \cdot 01)$, and $41 \%$ at $\mathrm{P} 45 \mathrm{~d}(t=5 \cdot 88, \quad P<0 \cdot 01)$ in hypothyroid rat myocardium, with the expression peak appearing until 2 weeks postnatally. Hence, in hypothyroid rats, myocardial TR $\alpha 1$ mRNA expression was generally downregulated and the expression peak appeared late (Fig. 4).

In normal rat myocardium, TR $\alpha 2$ mRNA expression was the highest at birth and then decreased gradually to the adult levels. Compared with normal rat myocardium, TR $\alpha 2$ mRNA expression was upregulated by $27 \%$ at $\mathrm{P} 0 \mathrm{~d}$ $(t=7 \cdot 60, P<0 \cdot 01), 71 \%$ at P14d $(t=20 \cdot 94, P<0 \cdot 01), 78 \%$ at P21d $(t=22 \cdot 05, P<0 \cdot 01)$, and $36 \%$ at P45d $(t=9 \cdot 46$, $P<0.01)$ in hypothyroid rat myocardium, with the expression peak appearing until 2 weeks postnatally. Hence, in hypothyroid rats, myocardial TR $\alpha 2$ mRNA expression was generally upregulated and the expression peak appeared late (Fig. 5).

In normal rat myocardium, TR $\beta 1$ mRNA expression reached a peak at P14d and then decreased gradually to the adult levels. Compared with normal rat myocardium, TR $\beta 1$ mRNA expression was downregulated by $75 \%$ at $\mathrm{P} 0 \mathrm{~d}$ $(t=61 \cdot 97, P<0 \cdot 01), 64 \%$ at $\mathrm{P} 14 \mathrm{~d}(t=9 \cdot 44, P<0 \cdot 01), 66 \%$ at $\mathrm{P} 21 \mathrm{~d}(t=30 \cdot 86, P<0 \cdot 01)$, and $67 \%$ at $\mathrm{P} 45 \mathrm{~d}(t=11 \cdot 25$, $P<0 \cdot 01)$ in hypothyroid rat myocardium. Hence, in hypothyroid rats, myocardial TR $\beta 1 \mathrm{mRNA}$ expression was generally downregulated and changed similarly with the control group (Fig. 6).

\section{Pathologic study}

Observations of HE-stained sections showed no morphological differences of myocardium between control P0d and hypothyroid P0d rats. In all POd rats, myocardial pedomorphism was observed, i.e., myocardial cells contained a little sarcoplasm, but no myofibrils or transverse striations, and cell boundary was indistinct. In the control group, myocardial sarcoplasm became abundant and obvious myofibrils or transverse striations were observed at P14d, P21d, and P45d. In contrast, in hypothyroid group, myocardial cell maldevelopment was observed at 14 and 21 days postnatally, with a little sarcoplasm, a thin and long cell shape, and

Table 4 Body weight (BW), serum free tri-iodothyronine $\left(\mathrm{FT}_{3}\right)$ and free thyroxine $\left(\mathrm{FT}_{4}\right)$ levels in each group $(n=12, \bar{X} \pm S)$

\begin{tabular}{|c|c|c|c|}
\hline & BW (g) & $\mathbf{F T}_{\mathbf{3}}(\mathrm{pmol} / \mathrm{l})$ & $\mathbf{F T}_{\mathbf{4}}(\mathrm{pmol} / \mathrm{l})$ \\
\hline \multicolumn{4}{|l|}{ Group } \\
\hline \multicolumn{4}{|l|}{ Control } \\
\hline Od & $6 \cdot 80 \pm 0 \cdot 68$ & $0 \cdot 20 \pm 0 \cdot 08$ & $3 \cdot 98 \pm 0 \cdot 70$ \\
\hline $14 d$ & $35 \cdot 11 \pm 2 \cdot 73$ & $1 \cdot 31 \pm 0 \cdot 29$ & $92 \cdot 18 \pm 30 \cdot 43$ \\
\hline $21 d$ & $61 \cdot 19 \pm 3 \cdot 79$ & $1 \cdot 4 \pm 0 \cdot 32$ & $53 \cdot 20 \pm 6 \cdot 85$ \\
\hline $45 d$ & $169 \cdot 55 \pm 13 \cdot 12$ & $1 \cdot 51 \pm 0 \cdot 28$ & $73 \cdot 41 \pm 19 \cdot 78$ \\
\hline \multicolumn{4}{|c|}{ Hypothyroid } \\
\hline Od & $5 \cdot 48 \pm 0.53 *$ & $0 \cdot 10 \pm 0 \cdot 05^{*}$ & $1 \cdot 77 \pm 0 \cdot 25^{*}$ \\
\hline $14 d$ & $24 \cdot 04 \pm 2 \cdot 66^{*}$ & $0.55 \pm 0.11 *$ & $4 \cdot 69 \pm 1 \cdot 82^{*}$ \\
\hline $21 d$ & $39 \cdot 19 \pm 4 \cdot 55^{*}$ & $0 \cdot 86 \pm 0.26^{*}$ & $28 \cdot 24 \pm 4 \cdot 46^{*}$ \\
\hline $45 d$ & $124 \cdot 26 \pm 14 \cdot 13^{*}$ & $1 \cdot 42 \pm 0 \cdot 48$ & $65 \cdot 57 \pm 6 \cdot 31$ \\
\hline
\end{tabular}

The body weight, $\mathrm{FT}_{3} \mathrm{~T}_{4}$ of P0d, P14d, and P21d hypothyroid rats were lower than those in the P0d, $\mathrm{P} 14 \mathrm{~d}$, and P21d control group respectively. ${ }^{*} P<0 \cdot 01$ versus control group. 


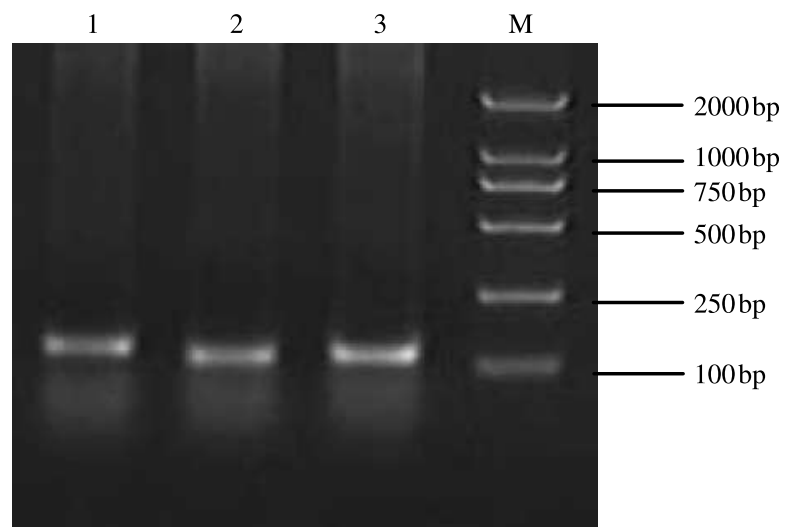

Figure 1 PCR results of $T R \alpha 1, T R \alpha 2$, and $T R \beta 1$.

indistinct transverse striations. Moreover, Henle's fissures (spaces between myocardial cells) were widened and myocardial cells were deranged focally. At 45 days postnatally, in the hypothyroid group, myocardial transverse striations can be observed, but sarcoplasm was still not abundant and cells were thin and long, with widened Henle's fissures (Fig. 7).

\section{Discussion}

The heart is a major target organ for thyroid hormone $\left(\mathrm{T}_{3}\right)$ action, and marked changes occur in cardiac faction in patients with hypo- or hyperthyroidism. $\mathrm{T}_{3}$ significantly influences cardiac contractile and electrophysiological function with increasing amounts of $\mathrm{T}_{3}$ enhancing cardiac contractile function and accelerating $\mathrm{HR}$. These effects are mediated by the binding of $\mathrm{T}_{3}$ to specific nuclear TRs. TRs are members of a family of nuclear receptors that includes steroid, retinoic acid, and vitamin D receptors, all closely related to the v-erbA oncogene. TRs are encoded by two different genes: $\operatorname{TR} \alpha$ on chromosome 17 and $\operatorname{TR} \beta$ on chromosome 3. TR $\alpha$ and $\operatorname{TR} \beta$ isoforms have a similar structure, characterized by an amino-terminal domain, a DNA-binding domain comprises two zinc finger motifs, and a carboxy-terminal ligand-binding domain. The TR $\alpha$ gene generates the TR $\alpha 1$ and TR $\alpha 2$ isoforms that are identical for

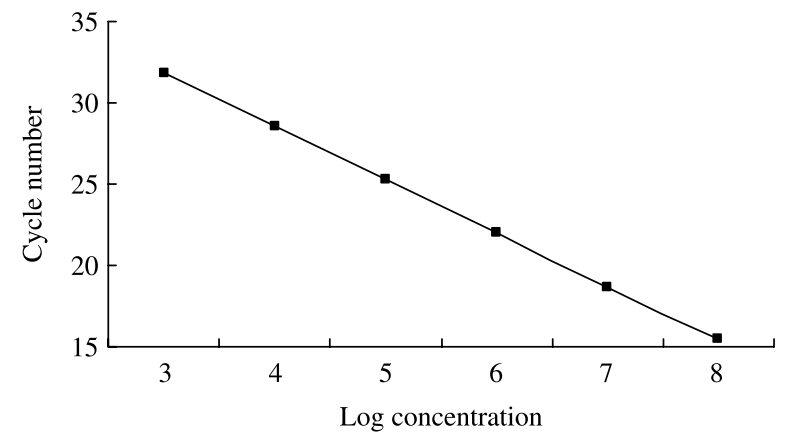

Figure 2 FQ-PCR standard curve.

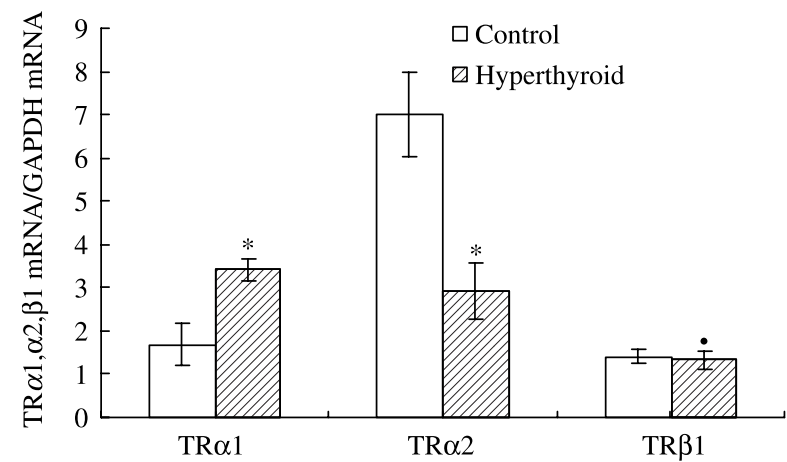

Figure 3 FQ-PCR analysis of TR $\alpha 1, T R \alpha 2$, and TR $\beta 1$ mRNA expression differentiations between control and hyperthyroid rat myocardium ( $\bar{X} \pm S, n=8)$. The TR $\alpha 1$ mRNA expression was upregulated by $51 \%$, TR $\alpha 2$ mRNA expression was downregulated by $58 \%$, and TR $\beta 1$ mRNA expression remained unchanged in hyperthyroid rat myocardium. ${ }^{*} P<0 \cdot 01, \cdot P<0 \cdot 05$ compared with the control group.

the first 370 amino acids but differ as a consequence of differential splicing at their $\mathrm{C}$ terminus: the last 40 specific residues of TR $\alpha 1$ are replaced by 122 amino acids encoded by the TR $\alpha 2$-specific exon 10 , the last exon in the TR $\alpha$ locus. As a consequence of the C-terminal change, the TR $\alpha 2$ protein is unable to bind $\mathrm{TH}$ and no other ligand has been identified. TR $\alpha 2$ binds DNA weakly and only binds a subset of $\mathrm{T}_{3}$-responsive sites. Furthermore, it dimerizes poorly with RXR and lacks the activating function domain 2 that interacts with coactivators. Both TR $\alpha 1$ and TR $\alpha 2$ mRNA are widely distributed. Alternative promoters or splicing of the amino-terminal region of the TR $\beta$ mRNA forms TR $\beta 1$ and TR $\beta 2$ in rat, both of which bind $T_{3}$. The TR $\beta 2$ mRNA is concentrated primarily in the anterior pituitary and the central nervous system of the rat, whereas the TR $\beta 1$ mRNA is widely distributed. Therefore, in our experiments,

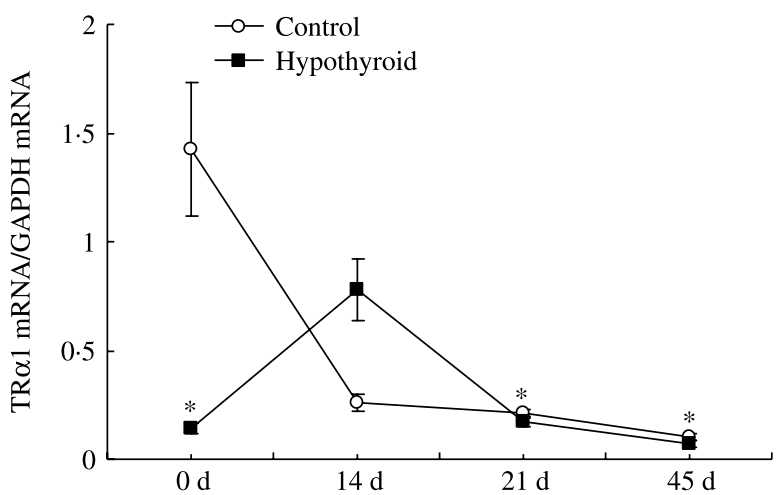

Figure 4 FQ-PCR analysis of TR $\alpha 1$ mRNA expression differentiations between control and hypothyroid rat myocardium $(\bar{X} \pm S$, $n=5)$. Compared with normal rat myocardium, TR $1 \mathrm{mRNA}$ expression was downregulated by $90 \%$ at P0d, $25 \%$ at P21d, and $41 \%$ at $\mathrm{P} 45 \mathrm{~d}$ in hypothyroid rat myocardium, with the expression peak appearing until 2 weeks postnatally. ${ }^{*} P<0 \cdot 01$ compared with the control group. 


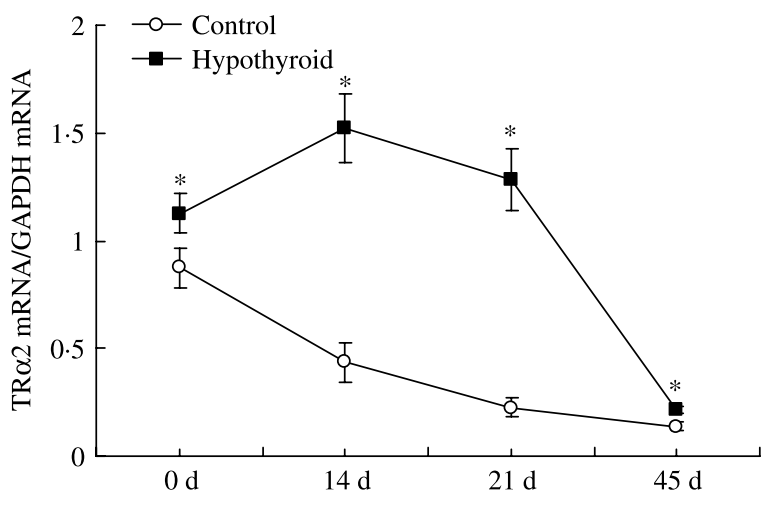

Figure 5 FQ-PCR analysis of TR $\alpha 2$ mRNA expression differentiations between control and hypothyroid rat myocardium $(\bar{X} \pm S$, $n=5)$. TR $\alpha 2$ mRNA expression was upregulated by $27 \%$ at P0d, $71 \%$ at $\mathrm{P} 14 \mathrm{~d}, 78 \%$ at $\mathrm{P} 21 \mathrm{~d}$, and $36 \%$ at $\mathrm{P} 45 \mathrm{~d}$ in hypothyroid rat myocardium, with the expression peak appearing until 2 weeks postnatally. ${ }^{*} P<0.01$ compared with the control group.

we detected TR $\alpha 1, T R \alpha 2$, and TR $\beta 1$ mRNA alterations except $\beta 2$. In addition, $\operatorname{TR} \alpha 1$ and $\operatorname{TR} \beta 1$ are thyroid hormone functional receptors except $\mathrm{TR} \alpha 2$ (Sap et al. 1986, Weinberger et al. 1986, Thompson et al. 1987, Lazar \& Chin 1990).

In our experiment, the phenotype of the hyperthyroid rat has features of hyperthyroidism, including slowly increased $\mathrm{BW}$, elevated HR, cardiac hypertrophy, and higher serum $\mathrm{FT}_{3}$ and $\mathrm{FT}_{4}$ levels. The phenotype of the hypothyroid rat also has features of $\mathrm{CH}$, such as slow growth, late weaning, poor balancing capability, slower reaction to stimuli, and lower serum $\mathrm{FT}_{3}$ and $\mathrm{FT}_{4}$ levels. Thus, the animal models were made successfully.

Our results have shown that TR $\alpha 1$ mRNA expression was upregulated, TR $\alpha 2$ mRNA expression was downregulated, but TR $\beta 1$ mRNA expression remained unchanged in the hyperthyroid rat myocardium compared with the normal myocardium. This may be because: 1) TR $\alpha 1$ is the major functional receptor in the myocardium; deficiency in TR isoforms caused discrete alterations in $\mathrm{HR}$ and ventricular

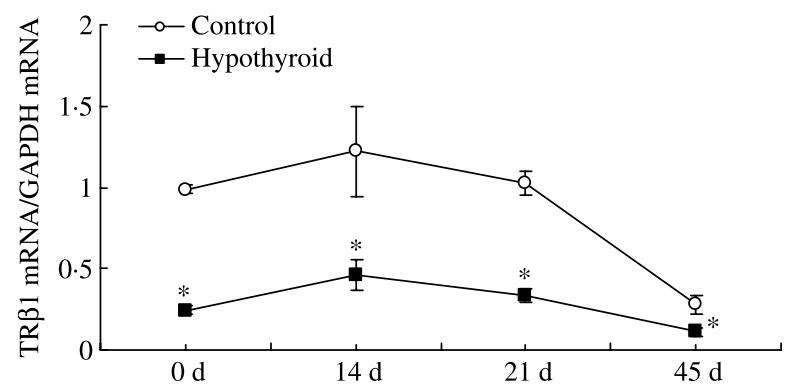

Figure 6 FQ-PCR analysis of TR $\beta 1$ mRNA expression differentiations between control and hypothyroid rat myocardium $(\bar{X} \pm S$, $n=5)$. TR $\beta 1$ mRNA expression was downregulated by $75 \%$ at POd, $64 \%$ at $\mathrm{P} 14 \mathrm{~d}, 66 \%$ at $\mathrm{P} 21 \mathrm{~d}$, and $67 \%$ at $\mathrm{P} 45 \mathrm{~d}$ in hypothyroid rat myocardium. ${ }^{*} P<0 \cdot 01$ compared with the control group.
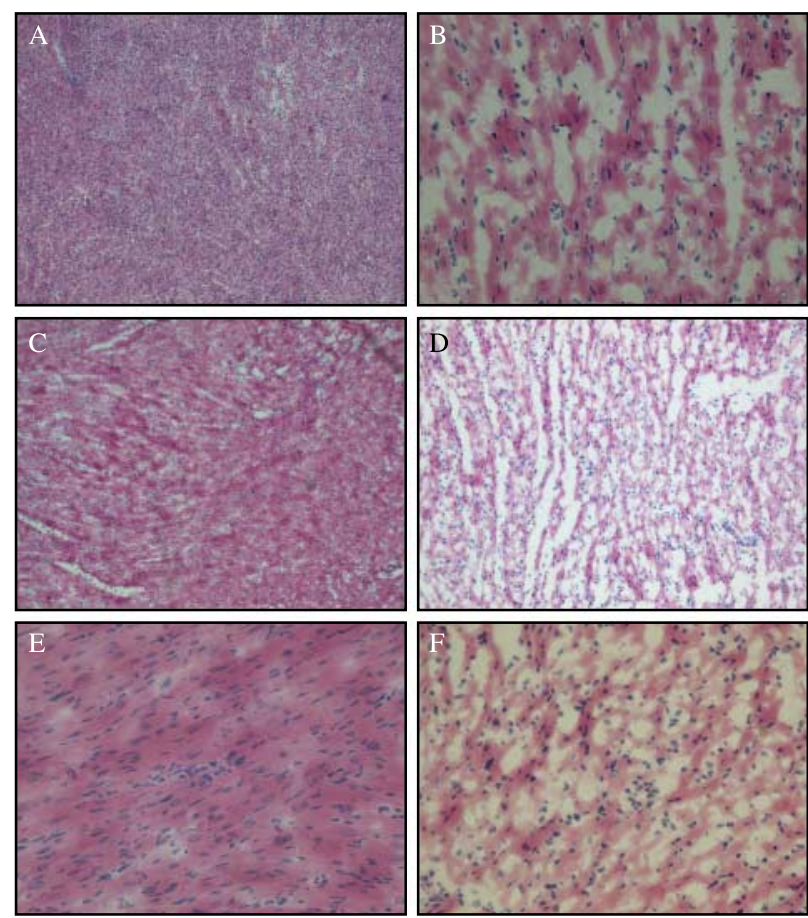

Figure 7 Observe the morphological differences of myocardium between control group and hypothyroid group rat. (A) Rat myocardium in POd control group, HE staining, $100 \times$. (B) Rat myocardium in P45d hypothyroid group (myocardial transverse striations can be observed, but sarcoplasm was still not abundant, with widened Henle's fissures.), HE staining, 400×. (C) Rat myocardium in $\mathrm{P} 21 \mathrm{~d}$ control group, HE staining, $200 \times$. (D) Rat myocardium in P21d hypothyroid group (with widened Henle's fissures, myocardial cells were deranged focally), HE staining, $200 \times$. (E) Rat myocardium in P21d control group, HE staining, $400 \times$. (F) Rat myocardium in P21d hypothyroid group (with a little sarcoplasm and indistinct transverse striations), HE staining, $400 \times$.

function. The TR $\alpha 1^{-/-}$mice exhibited lower HR, lower body temperature, and slower ventricular repolarization (prolonged $\mathrm{P}-\mathrm{Q}, \mathrm{QRS}$, and $\mathrm{Q}-\mathrm{T}$ durations in the $\mathrm{ECG}$ ) as compared with normal mice. The TR $\beta^{-\prime-}$ mice exhibited severely impaired hearing, normal HR as well as normal contractile function of papillary muscle (Forrest et al. 1996a,b, Rüsch et al. 1998, Wikström et al. 1998, Göthe et al. 1999, Johansson et al. 1999). Comparison of the cardiac phenotype between $\operatorname{TR} \alpha$ and TR $\beta$ KO mice clearly indicates that $\operatorname{TR} \alpha$ had predominant contractile and electrophysiological function in the heart. Furthermore, TR $\alpha 1$ mRNA was present at a 3:1 ratio to TR $\beta$ mRNA in the ventricle of the heart (Swanson et al. 2003). These findings indicated that the cardiac phenotype regulated by $\mathrm{T}_{3}$ was primarily mediated by the more predominant $\operatorname{TR} \alpha$ in the heart. The lack of TR $\alpha$ cannot be compensated by TR $\beta$ in the heart, but the lack of TR $\beta$ can be compensated by TR $\alpha$ in the heart (Gloss et al. 2001). The TR $\alpha 1$ exerts a predominant effect on cardiac electrophysiological functions. Thus, at high thyroid hormone level, the expression of TR $\alpha 1$, the major functional 
receptor of thyroid hormones in the myocardium was upregulated in a compensatory manner. 2) The TR $\alpha 2$ has been suggested to exert a suppressive function on other TRs. Suggested mechanisms for suppression include competition for binding to thyroid hormone response elements (TREs) on target genes, formation of inactive heterodimers, or squelching (Rentoumis et al. 1990, Katz et al. 1992, Katz \& Lazar 1993, Liu et al. 1995, Tagami et al. 1998). Transient transfection of the cDNA coding for TR $\alpha 2$ has been shown to block the effect of a co-transfected $\alpha 1$ or $\beta 1$ cDNA in facilitating $\mathrm{T}_{3}$ regulation of a third co-transfected reporter gene (Koenig et al. 1989, Strait et al. 1990). This blockade has been ascribed to an ability of the TR $\alpha 2$ protein to compete with $\alpha 1$ and $\beta 1$ for the TRE situated in the $5^{\prime}$-flanking region of the reporter gene. In addition, selective ablation of $\mathrm{TR} \alpha 2$ resulted in an inevitable, concomitant overexpression of TR $\alpha 1$ (Saltó et al. 2001). So downregulation of TR $\alpha 2$ mRNA expression attenuates the inhibition of $\mathrm{TR} \alpha 1$ by $\mathrm{TR} \alpha 2$ and leads to upregulation of TR $\alpha 1$ expression. Upregulated TR $\alpha 1$ can lead to heart lesions through modulating the expression of $\mathrm{T}_{3}$-regulated genes. MHC has a high ATPase activity and is closely related to fast myocardial contraction. The TR $\alpha 1$ expression upregulation may upregulate the expression of $\mathrm{MHC} \alpha$ mRNA and enhance myocardial inotropy (Kinugawa et al. 2001). A long-term hyperkinetic state of myocardium causes myocardial strain to progress from the compensated to the decompensated stage. $\mathrm{Na}^{+} / \mathrm{H}^{+}$exchanger-1 (NHE1) is a plasma membrane protein that removes an intracellular proton, exchanging it with extracellular sodium. By doing so, the NHE1 raises intracellular $\mathrm{pH}$. The TR $\alpha 1$ can activate the NHE1 exchanger promoter (Li et al. 2002). The TR $\alpha 1$ expression upregulation may lead to NHE1 overactivation, thus causes acidosis in myocardial cells and progressive degeneration and even necrosis of myocardial cells. These changes are consistent with myocardial pathological changes in patients with chronic hyperthyroid heart disease.

Thyroid hormone signaling is critical for proper heart development and function. $\mathrm{T}_{3}$ can increase expressions of myocardium-specific TH-responsive genes. Myocardiumspecific genes comprise a list of proteins responsible for cardiomyocyte function: MHC, SERCA2, $\boldsymbol{\alpha}_{-}$and $\beta$-adrenergic receptors, several plasma membrane ion transporters, such as $\mathrm{Na}^{+} / \mathrm{Ca}^{2+}$ exchanger, NHE, and a variety of ion channels, including HCN2, HCN4, Kv1.5, Kv4.2, and Kv4.3. They can be regulated at both the transcriptional and post-transcriptional levels by $\mathrm{T}_{3}$ binding with specific nuclear TRs, thus coordinating the electrochemical and mechanical responses of the myocardium (Ma et al. 2003, Kahaly \& Dillmann 2005). TH-responsive gene promoters are selectively regulated by the various TR isoforms. For example, TR $\alpha 1$ can activate the $\alpha$-MHC, HCN2, and HCN4 promoter and TR $\beta 1$ can activate the HCN4 promoter and repress the $\beta$-MHC promoter (Gloss et al. 2001). Our experiment showed that in hypothyroid rats, TR $\alpha 1$ mRNA expression was generally downregulated and the expression peak appeared late, and
TR $\beta 1$ mRNA expression was generally downregulated. Downregulated TRa1 and TR $\beta 1$ mRNA expression will lead to the decreased expression of HCN2, HCN4, MHCa, and SERCA2. HCN2 and HCN4 have been identified as components of an ion channel that constitutes the $\mathrm{I}_{\mathrm{f}}$ current, which contributes to HR generation. Markedly decreased expression of HCN2 and HCN4 occurs in TR $\alpha \mathrm{KO}$ mice and euthyroid TR $\beta$ PV with a decreased HR (Gloss et al. 2001). $M H C \alpha$ mRNA code protein that is linked to force generation. SERCA2 mRNA code protein that is linked to calcium lowering during diastole, so decreased levels of $\mathrm{MHCa}$ mRNA and SERCA2 mRNA may provide the cause for slowed force development and prolonged relaxation time. Thus, the abnormal expressions of myocardium-specific genes caused myocardial structural developmental abnormalities and serious heart dysfunction. These changes are consistent with myocardium pathological changes in patients with chronic hypothyroid heart disease.

Abnormal expressions of TR subtypes in hypothyroid adult rat myocardium have been reported previously, but the results were inconsistent, possibly due to different preparation methods of animal models and different detection methods adopted by those laboratories. In the present study, we established congenital hypothyroid rats and monitored the influence of $\mathrm{CH}$ on myocardial TR subtypes expressions from birth through adulthood. We not only reported the changes of myocardial TR expressions in normal rats throughout the developmental process, but also demonstrated delayed peaks and downregulation of expressions of functional receptors of thyroid hormone in hypothyroid rats. In addition, the study confirmed that $\mathrm{CH}$ caused myocardial maldevelopment (less sarcoplasm in the thin and long cell, transverse striations development delay and widened Henle's fissures) may be closely associated with abnormal TR expressions. TR $\alpha 1$ and TR $\beta 1$ are functional receptors of thyroid hormones in the myocardium, and downregulated TR $\alpha 1$ and TR $\beta 1$ expression may lead to abnormal expression of multiple genes regulated by thyroid hormones, thus resulting in a series of electrophysiological abnormalities of the heart and myocardial functional injury. In addition, thyroid hormones are crucial for myocardial development and they may promote myocardial cell survival. Lack of thyroid hormones in the embryonic stage may induce myocardial cell apoptosis and downregulate the mRNA expressions of functional thyroid hormones receptors (Alisi et al. 2005, Verga et al. 2006).

At an early stage of the experiment, we wanted to establish a neonatal hyperthyroidism model to monitor the influences of hyperthyroid on myocardial TR expressions from birth through adulthood, but the mortality of pregnant and neonate rat were so high that adequate samples cannot be obtained. Considering hyperthyroidism is more common in adults than in children, we had to alter the experiment design. We had to give up the neonate hyperthyroidism model and establish an adult hyperthyroidism model to detect the effect of thyroid hormone on the adult hyperthyroid rat myocardium. In the future, we 
plan to study TR's differential expressions in hyperthyroid developmental myocardium on the basis of this article.

In summary, the present study demonstrated that abnormal thyroid hormone concentrations caused abnormal TR mRNA expressions in the myocardium. During hyperthyroidism, high thyroid hormone level may influence the transcription level of TR and lead to faster HR and a hyperkinetic state of the heart by influencing the expressions of thyroid hormone-regulated genes. Hence, a long-term exposure to high thyroid hormone level will lead to heart failure. During $\mathrm{CH}$, TR mRNA expression peak appeared late and abnormal expression changes of TRs occurred in the myocardium, which resulted in maldevelopment of myocardial cells and conduction bundles, irreversible damage to myocardial structure and function, and ultimately hypothyroid heart disease. Therefore, in the presence of thyroid dysfunction, abnormal expressions of TR subtypes in the myocardium are closely associated with the pathogenesis of heart lesions. The present study not only deepened the understanding of pathogenesis of thyroid dysfunction caused heart lesions, but also may guide gene therapy and the selective application of various TR subtype antagonists for such heart lesions.

\section{Acknowledgements}

This research was supported by Natural Science Foundation of Tianjin (033605711), Science and Technology Development Program of Tianjin (05YFGDSF02700) and Chinese People's Armed Police Force Foundation (wy2006-4). We are grateful to Jason Tam, Miao jun, and Miao Jie for English revision. The authors declare that there is no conflict of interest that would prejudice the impartiality of this scientific work.

\section{References}

Alisi A, Demori I, Spagnuolo S, Pierantozzi E, Fuqassa E \& Leoni S 2005 Thyroid status affects rat liver regeneration after partial hepatectomy by regulating cell cycle and apoptosis. Cellular Physiology and Biochemistry 15 $69-76$.

Balducci G, Acquafredda A, Amendola F, Natuzzi M, Laforgia N \& Cavallo L 1991 Cardiac function in congenital hypothyroidism: impairment and response to $\mathrm{L}_{-} \mathrm{T}_{4}$ therapy. Pediatric Cardiology 12 28-32.

Basset A, Blanc J, Messas E, Hagege A \& Elghozi JL 2001 Renin-angiotensin system contribution to cardiac hypertrophy in experimental hyperthyroidism: an echocardiographic study. Journal of Cardiovascular Pharmacology 37 $163-172$

Chao T, Wang JR \& Hwang B 1997 Congenital hypothyroidism and concomitant anomalies. Journal of Pediatric Endocrinology and Metabolism 10 217-221.

Dillmann WH 1990 Biochemical basis of thyroid hormone action in the heart. American Journal of Medicine 88 626-630.

Dillmann WH 1996 Thyroid hormone action and cardiac contractility - a complex affair. Endocrinology 137 799-801.

Dillmann WH 2002 Celluar action of thyroid hormone on the heart. Thyroid 12 447-452.

Forrest D, Erway LC, Ng L, Altschuler R \& Curran T 1996a Thyroid hormone receptor beta is essential for development of auditory function. Nature Genetics 13 354-357.
Forrest D, Hanebuth E, Smeyne RJ, Everds N, Stewart CL, Wehner JM \& Curran T 1996b Recessive resistance to thyroid hormone in mice lacking thyroid hormone receptor beta: evidence for tissue-specific modulation of receptor function. EMBO Journal 15 3006-3015.

Gilbert ME \& Paczkowski C 2003 Propylthiouracil (PTU)-induced hypothyroidism in the developing rat impairs synaptic transmission and plasticity in the dentate gyrus of the adult hippocampus. Brain Research. Developmental Brain Research 145 19-29.

Gloss B, Trost S, Bluhm W, Swanson E, Clark R, Winkfein R, Janzen K, Giles W, Chassande O, Samarut J et al. 2001 Cardiac ion channel expression and contractile function in mice with deletion of thyroid hormone receptor alpha or beta. Endocrinology 142 544-550.

Göthe S, Wang Z, Ng L, Kindblom JM, Barros AC, Ohlsson C, Vennström B \& Forrest D 1999 Mice devoid of all known thyroid hormone receptors are viable but exhibit disorders of the pituitary-thyroid axis, growth, and bone maturation. Genes and Development 13 1329-1341.

Johansson C, Göthe S, Forrest D, Vennström B \& Thorén P 1999 Cardiovascular phenotype and temperature control in mice lacking thyroid hormone receptor-beta or both alpha1 and beta. American Journal of Physiology 276 H2006-H2012.

Kahaly GJ \& Dillmann WH 2005 Thyroid hormone action in the heart. Endocrine Reviews 26 704-728.

Katz AM 1990 Angiotensin II: hemodynamic regulator or growth factor? Journal of Molecular and Cellular Cardiology 22 739-747.

Katz D \& Lazar MA 1993 Dominant negative activity of an endogenous thyroid hormone receptor variant (alpha 2) is due to competition for binding sites on target genes. Journal of Biological Chemistry 268 20904-20910.

Katz D, Berrodin TJ \& Lazar MA 1992 The unique C-termini of the thyroid hormone receptor variant, c-erbA alpha 2, and thyroid hormone receptor alpha 1 mediate different DNA-binding and heterodimerization properties. Molecular Endocrinology 6 805-814.

Kinugawa K, Yonekura K, Ribeiro RC, Eto Y, Aoyagi T, Baxter JD, Camacho SA, Bristow MR, Long CS \& Simpson PC 2001 Regulation of thyroid hormone receptor isoforms in physiological and pathological cardiac hypertrophy. Circulation Research 89 591-598.

Klein I 1990 Thyroid hormone and the cardiovascular system. American Journal of Medicine 88 631-637.

Klein I \& Ojamaa K 2001 Thyroid hormone and the cardiovascular system. New England Journal of Medicine 344 501-509.

Koenig RJ, Lazar MA, Hodin RA, Brent GA, Larsen PR, Chin WW \& Moore DD 1989 Inhibition of thyroid hormone action by a non-hormone binding c-erbA protein generated by alternative mRNA splicing. Nature 337 659-661.

Lazar MA \& Chin WW 1990 Nuclear thyroid hormone receptors. Journal of Clinical Investigation 86 1777-1782.

Li X, Misik AJ, Rieder CV, Solaro RJ, Lowen A \& Fliegel L 2002 Thyroid hormone receptor alpha 1 regulates expression of the $\mathrm{Na}^{+} / \mathrm{H}^{+}$exchanger (NHE1). Journal of Biological Chemistry 277 28656-28662.

Liu RT, Suzuki S, Miyamoto T, Takeda T, Ozata M \& DeGroot LJ 1995 The dominant negative effect of thyroid hormone receptor splicing variant alpha 2 does not require binding to a thyroid response element. Molecular Endocrinology 9 86-95.

Ma ML, Watanabe K, Watanabe H, Hosaka Y, Komura S, Aizawa Y \& Yamamoto T 2003 Different gene expression of potassium channels by thyroid hormone and an antithyroid drug between the atrium and ventricle of rats. Japanese Heart Journal 44 101-110.

Maixent JM, Barbey O, Pierre S, Duran MJ, Sennoune S, Bourdeaux M, Ricard P \& Lévy S 2000 Inhibition of Na, K-ATPase by external electrical cardioversion in a sheep model of atrial fibrillation. Journal of Cardiovascular Electrophysiology 11 439-445.

Marchant C, Brown L \& Semia C 1993 Renin-angiotensin system in thyroid dysfunction in rats. Journal of Cardiovascular Pharmacology 22 449-455.

Di Meo S, de Martino Rosaroll P, Piro MC \& De leo T 1994 Ventricular electrophysiological properties in normal and congenitally hypothyroid neonatal rats. Archives Internationales de Physiologie, de Biochimie et de Biophysique 102 129-134.

Morgan HE \& Baker KM 1991 Cardiac hypertrophy. Mechanical, neural, and endocrine dependence. Circulation 83 13-25. 
Morreale de Escobar G, Obregon MJ, Ruiz de Oña C \& Escobar del Rey F 1988 Transfer of thyroxine from the mother to the rat fetus near term: effects on brain 3,5,3'-triiodothyronine deficiency. Endocrinology 122 1521-1531.

Polikar R, Burger AG, Scherrer U \& Nicod P 1993 The thyroid and the heart. Circulation 87 1435-1441.

Rensma PL, Allessie MA, Lammers WJ, Bonke FI \& Schalij MJ 1988 Length of excitation wave and susceptibility to reentrant atrial arrhythmias in normal conscious dogs. Circulation Research 62 395-410.

Rentoumis A, Chatterjee VK, Madison LD, Datta S, Gallagher GD, Degroot LJ \& Jameson JL 1990 Negative and positive transcriptional regulation by thyroid hormone receptor isoforms. Molecular Endocrinology 4 1522-1531.

Rüsch A, Erway LC, Oliver D, Vennström B \& Forrest D 1998 Thyroid hormone receptor beta-dependent expression of a potassium conductance in inner hair cells at the onset of hearing. PNAS 95 15758-15762.

Saltó C, Kindblom JM, Johansson C, Wang Z, Gullberg H, Nordström K, Mansén A, Ohlsson C, Thorén P, Forrest D \& Vennström B 2001 Ablation of TRalpha2 and a concomitant overexpression of alpha1 yields a mixed hypoand hyperthyroid phenotype in mice. Molecular Endocrinology 15 2115-2128.

Sap J, Muñoz A, Damm K, Goldberg Y, Ghysdael J, Leutz A, Beug H \& Vennström B 1986 The c-erb-A protein is a high-affinity receptor for thyroid hormone. Nature 324 635-640.

Sernia C, Marchant C, Brown L \& Hoey A 1993 Cardiac angiotensin receptors in experimental hyperthyroidism in dogs. Cardiovascular Research 27 423-428.

Strait KA, Schwartz HL, Perez-Castillo A \& Oppenheimer JH 1990 Relationship of c-erbA mRNA content to tissue triiodothyronine nuclear binding capacity and function in developing and adult rats. Journal of Biological Chemistry 265 10514-10521.

Sussman MA 2001 When the thyroid speaks, the heart listens. Circulation Research 89 557-559.

Swanson EA, Gloss B, Belke DD, Kaneshige M, Cheng SY \& Dillmann WH 2003 Cardiac expression and function of thyroid hormone receptor beta and its PV mutant. Endocrinology 144 4820-4825.
Tagami T, Kopp P, Johnson W, Arseven OK \& Jameson JL 1998 The thyroid hormone receptor variant alpha 2 is a weak antagonist because it is deficient in interactions with nuclear receptor corepressors. Endocrinology 139 2535-2544.

Thompson CC, Weinberger C, Lebo R \& Evans RM 1987 Identification of a novel thyroid hormone receptor expressed in the mammalian central nervous system. Science 237 1610-1614.

Verga Falzacappa C, Panacchia L, Bucci B, Stiqliano A, Cavallo MG, Brunetti E, Toscano V \& Misiti S 2006 3,5,3'-triiodothyronine (T3) is a survival factor for pancreatic beta-cells undergoing apoptosis. Journal of Cellular Physiology 206 309-321.

Weinberger C, Thompson CC, Ong ES, Lebo R, Gruol DJ \& Evans RM 1986 The $c$-erb- $A$ gene encodes a thyroid hormone receptor. Nature 324 641-646.

Wijffels MC, Kirchhof CJ, Dorland R \& Allessie MA 1995 Atrial fibrillation begets atrial fibrillation. A study in awake chronically instrumented goats. Circulation 92 1954-1968.

Wikström L, Johansson C, Saltó C, Barlow C, Campos Barros A, Baas F, Forrest D, Thorén P \& Vennström B 1998 Abnormal heart rate and body temperature in mice lacking thyroid hormone receptor alpha 1. EMBO Journal 17 455-461.

Workman AJ, Kane KA \& Rankin AC 2003 Characterisation of the Na, K pump current in atrial cells from patients with and without chronic atrial fibrillation. Cardiovascular Research 59 593-602.

Received in final form 9 September 2007

Accepted 19 September 2007

Made available online as an Accepted Preprint 19 September 2007 